\title{
A Crushing Load of COVID-19 at Maharashtra: Indian Epicenter of the SARS-CoV-2 Pandemic
}

\section{Indranil Chatterjee ${ }^{1 *}$, Toumica Ghosh ${ }^{1}$, Sanchari Chatterjee ${ }^{1}$, Suman Kumar Nath ${ }^{1}$, Rakhi Bakuli ${ }^{2}$ and Soumitra Sahana ${ }^{3}$}

${ }^{1}$ Assistant Professor, Birbhum Pharmacy School, Birbhum, West Bengal, India

${ }^{2}$ Assistant Professor, P.G Institute of Medical Sciences, Chandrakona Town, Paschim

Midnapore, West Bengal, India

${ }^{3}$ B. Pharm, Birbhum Pharmacy School, Birbhum, West Bengal, India

*Corresponding Author: Indranil Chatterjee, Assistant Professor, Birbhum

Pharmacy School, Birbhum, West Bengal, India.

Medical clinics are overpowered with the devastating heap of COVID-19 cases and are experiencing deficiencies of individual defensive gear (Personal Protective Equipment) for care suppliers. More than 67,000 Indians have affected with COVID-19 till date, out of which 20,917 have been recovered with more than 2,206 of them are died. 22,171 cases overview from Maharashtra state alone out of which 832 have lost their life and remaining are under treatment and sent for quarantine (Figure 1). Since lateApril, either by choice or in response to shelter-in-place orders, most Indians have been staying home and limiting non-essential travel and industrial and business activity has slowed to a crawl. In a thick urban territory, most occupants have no entrance to private open-air space and depend on open parks for work out, the emotional well-being help that originates from an association with nature and outside air. Scrupulous city occupants presently contemplate how to keep up safe social separation while imparting restricted outside space to other people. Official proposals by the WHO have combined on $6 \mathrm{ft}$ of separation as the standard of thumb [1] for maintaining a strategic distance from the trading of possibly infective respiratory beads and vaporizers, however these suggestions were conceived based on perceptions made during the 1930s for medical clinic environments [2].

Do they hold for outside, in a breeze? During exercise? In certain spots, the outside air that we look for is fresher than before the pandemic. Shutdowns have brought about much lower discharges of toxins identified with movement and business action,
Received: June 25, 2020

Published: August 26, 2020

(C) All rights are reserved by Indranil

Chatterjee., et al.

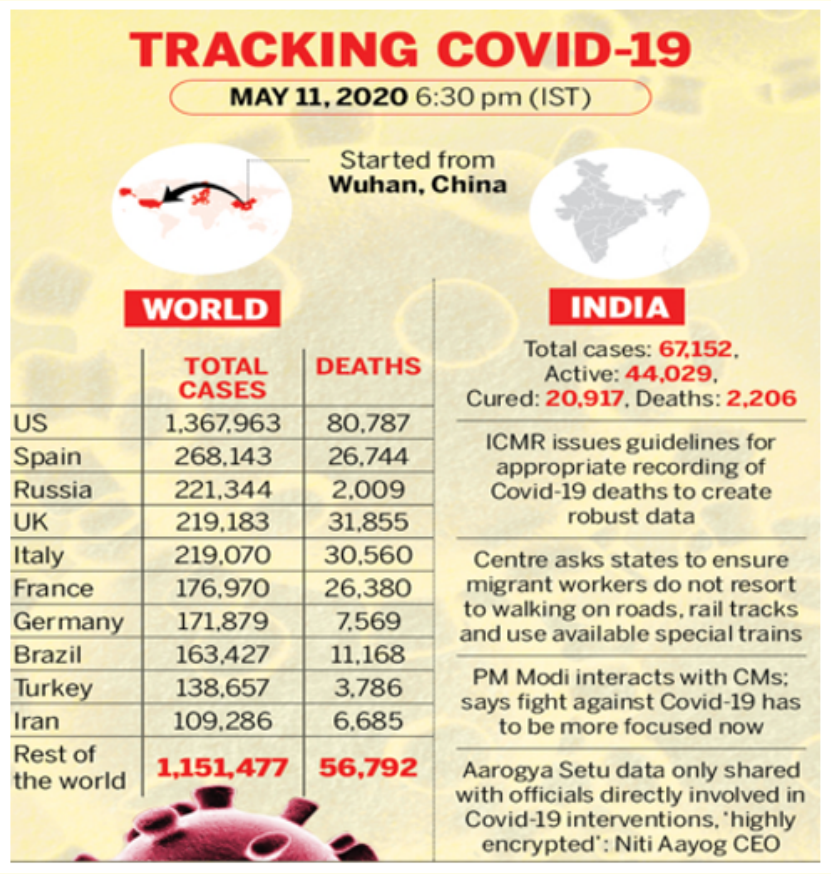

Figure 1: Statistical report of COVID-19 sourced by The Times of India.

yet different wellsprings of air contamination have stayed steady or even expanded. Family unit power use has expanded significantly, and utilization designs have moved because of our new, more seri- 
ously household way of life. These adjustments in outflows harmonize with the regular meteorological changes that accompany the progress from winter into spring, confounding the distinguishing proof and understanding of patterns from satellite information and long-haul observing systems. While air quality in Maharashtra is like earlier years, inhabitants are abounding in the abnormally clear skies that the mix of blustery climate and decreased vehicle traffic has provided [3].

Emotional upgrades in perceivability have been accounted for in certain territories of India, while in others, horticultural consuming and the utilization of strong energizes for family cooking has kept degrees of fine particulate issue high, regardless of shutdowns [4]. Long-term introduction to air contamination is related with a considerable lot of the ailments that put people at high hazard for confusions identified with COVID-19, including respiratory and cardiovascular conditions and diabetes. Examination of information from Italy [5] and the United States [6] has started to uncover an association between particulate issue with a distance across of under $2.5 \mu \mathrm{m}$ (PM2.5) presentation and COVID-19 passing.

In spite of any natural wedding trip that might be encountering an aftereffect of pandemic-related shutdowns, a headache can be normal as the economy revives and dirtying exercises continue. The United States Environmental Protection Agency (U.S. EPA) has loosened up authorization of natural guidelines during the crisis [7] and it isn't clear when these will be reestablished. Other contamination sources may likewise overshoot pre-pandemic levels. For instance, up to this point, riding the Metropolitan Transportation Authority (MTA) metro framework with more than 5 million individual travelers every day was a piece of the mood of Maharashtra life and a sign of economical city living. Suburbanites with alternatives might be delayed to re-embrace open transportation out of dread of presentation to SARSCoV-2 in packed conditions, depending rather on all the more dirtying methods of transportation.

Then again, commanded telecommute and worldwide limitations on business travel have constrained a mass specialized and social change in accordance with teaming up and associating on the web through videoconference. We may rise up out of this emergency with a lot higher bar for significant distance air travel for gatherings. Increasingly adaptable work-from-home approaches, notwithstanding supporting social removing in the questionable mid-term future, could prompt less traffic blockage and versatile source outflows than before the pandemic. The barometrical vaporized network has loaned their skill and research facility hardware to the testing of materials for natively constructed veils for their capacity to forestall the spread of respiratory beads or inward breath of infective pressurized canned products. Others have been associated with testing the presentation of N95 respirator covers after disinfection for reuse, or the little scope assembling of PPE, for example, face shields. Vaporized researchers have likewise said something to the open conversation about respiratory mist concentrates and the airborne spread of SARS-CoV-2 inside and outdoors [8].

Specialists on air quality and atmosphere have imparted bits of knowledge to the media, talking about the proof for the effects of the pandemic related shutdowns on nature and suggestions for future ecological approach. At long last, as the scholastics among residents have quickly acclimated to online instruction and the new needs and worries of their understudies, many have created and transparently shared instructive materials on the web. In spite of the fact that individuals remain socially separated for the present, it has been cheering to see the network meet up in this season of intense human and cultural need.

\section{Bibliography}

1. Centers for Disease Control and Prevention (CDC). Social Distancing, Quarantine, and Isolation; CDC: Atlanta, GA (2020).

2. Bourouiba L. "Turbulent Gas Clouds and Respiratory Pathogen Emissions: Potential Implications for Reducing Transmission of COVID-19". Journal of the American Medical Association (2020): E1-E2.

3. Schiermeier Q. "Why Pollution Is Plummeting in Some Cities. But Not Others". Nature (2020).

4. Noor, D. "Is the COVID-19 Lockdown Really Decreasing Air Pollution in India?" Earther; G/O Media, Inc.: New York (2020).

5. Conticini E., et al. "Can Atmospheric Pollution Be Considered a Co-Factor in Extremely High Level of SARS-CoV-2 Lethality in Northern Italy?" Environment Pollution (2020): 114465.

6. Wu X., et al. "Exposure to Air Pollution and COVID-19 Mortality in the United States". medRxiv (2020). 
7. Bodine SP. COVID-19 Implications for EPAs Enforcement and Compliance Assurance Program; United States Environmental Protection Agency (U.S. EPA): Washington, D.C (2020).

8. Asadi S Bouvier., et al. "The Coronavirus Pandemic and Aerosols: Does COVID-19 Transmit via Expiratory Particles?" Aerosol Science and Technology 1 (2020).

\section{Assets from publication with us}

- Prompt Acknowledgement after receiving the article

- Thorough Double blinded peer review

- Rapid Publication

- Issue of Publication Certificate

- High visibility of your Published work

Website: www.actascientific.com/

Submit Article: www.actascientific.com/submission.php

Email us: editor@actascientific.com

Contact us: +919182824667 